\title{
Considerations regarding the purchase behaviour for clothes made from recycled textile waste in Turkey \\ DOI: 10.35530/IT.072.01.1840
}

IONICA ONCIOIU

ANA MARIA IFRIM

MARIUS PETRESCU
ANCA GABRIELA PETRESCU

CĂTĂLIN PETCU

CĂTĂLIN IONUTT SILVESTRU

\begin{abstract}
REZUMAT
\section{Considerations regarding the purchase behaviour for clothes made from recycled textile waste in Turkey}

Today, more than ever, the increasing levels of recycled textile waste ratios in Turkey make a significant contribution to the development of a sustainable future at global level. This research paper aims to present the attitudes, motives and experiences of the Turkish purchase intention related to textile products coming from the recycling of unused, old or faulty textile products. A quantitative marketing research was carried out on a sample of over 650 participants on the data provided by the questionnaire which focuses on studying the consumer behaviour of textile products coming from the recycling of unused, old or faulty textile products, influenced by endogenous (psychological) and exogenous (sociological) variables. A series of general hypotheses and statistical assumptions were made, the results of which were presented through testing using a series of econometric formulas. The results show important aspects regarding the purchase intention of the textile products coming from the recycling of unused, old or faulty textile products and they also describe the evolution of the market shares of green textile products, based on the perceptions of the Turkish population.
\end{abstract}

Keywords: Turkish textile sector, environmentally friendly, eco-friendly clothing, financially sustainable, sustainability

Considerații privind comportamentul de cumpărare a hainelor confecționate din deșeuri textile reciclate din Turcia

Astăzi, mai mult ca oricând, nivelurile în creștere ale raporturilor de deșeuri textile reciclate din Turcia contribuie semnificativ la dezvoltarea unui viitor durabil la nivel global. Această lucrare de cercetare își propune să prezinte atitudinile, motivele și experiențele intenției de cumpărare a populației din Turcia în raport cu produsele textile provenite din materiale textile neutilizate, vechi sau defecte. O cercetare de marketing cantitativă a fost efectuată pe un eșantion de peste 650 de participanți la datele furnizate de chestionar care se concentrează pe studierea comportamentului consumatorului produselor textile provenite din reciclarea materialelor textile neutilizate, vechi sau defecte, influențate de variabile endogene (psihologice) și exogene (sociologice). Au fost făcute o serie de ipoteze generale și ipoteze statistice, ale căror rezultate au fost prezentate prin testare folosind o serie de formule econometrice. Rezultatele arată aspecte importante cu privire la intenția de cumpărare a produselor textile provenite din reciclarea materialelor textile neutilizate, vechi sau defecte și descriu, de asemenea, evoluția cotelor de piață ale produselor textile verzi, pe baza percepțiilor populației din Turcia.

Cuvinte-cheie: sectorul textil din Turcia, prietenos cu mediul, îmbrăcăminte ecologică, durabilitate financiară, sustenabilitate

\section{INTRODUCTION}

In the last years, the international market of green textile and clothing products, during the last years, has been in a continuous process of structural mutations [1-3]. As a consequence, the changing of the fundamental elements of the market had a significant influence on the exports from many less developed countries and with economies in transition, where the national incomes depend a lot on the export of green textile and clothing products. The clearest tendency in Europe for the next period is the focus of the retail trade in specialized chains, with an impact on the independent traders (they will represent about $44 \%$ of the green textile products distribution) [2].

On the other hand, increased competition and trade liberalization should contribute to the overall objective of sustainable development in all its dimensions (economic, social, and environmental). This poses challenges, such as how to avoid a race to gain or defend market shares resulting in a deterioration of the working conditions - already fragile - of some of the poorer people in the poorer countries: such non-respect of basic labour rights or a worsening of environmental standards should not be considered as part of the comparative advantages of any country [3-5].

In addition, the promotion of sustainable development should be done, as far as possible, through specialized international institutions where they exist, through enhanced cooperation between the EU and these institutions, and using proactive means and compliance with international standards. 
Turkey has achieved significant success in improving its textile recycling framework and reforming its public expenditure management system as well as key green textile product markets. The new Stand-by Arrangement and the EU accession create twin anchors for economic policies but strong implementation of the "Zero Waste" reforms is a necessary condition for maintaining the current policy performance [4].

The contribution of the textile industry at the growth of the Turkish economy is tremendous, having in mind the variety of the green products used in the most diverse activity fields. Among the foremost types of green textile products, we name part of an ambitious new waste management initiative [5]. On the other hand, success depends on the recycling technologies used, the high level of textile wastes collection and management.

The importance of the green material is huge, as presently the green technologies are in transition to a domain of green materials. They are multi component recycling materials, with ordered and specific structure, fact that pushes up the existent limits [5].

In order to reduce the gaps in the reuse and recycling of textile waste, the Turkish Government must provide the necessary resources to develop and implement effective textile waste management policies, to provide the necessary infrastructure for their collection and recycling, to set up business partnerships to collect them and recycle better [6]. From this point of view, Turkey intends to align itself with resolving issues related to textile waste management in the European Union.

In recent years, researchers pay more attention to textile products coming from the recycling of unused, old or faulty textile products and identified the following eco-friendly clothing purchase intention: (1) economically purchase motivated; (2) environmentally purchase motivated; (3) economically oriented reuse; (4) environmentally motivated reuse; and (5) awareness-based purchasing [7-11].

Other authors interpreted their analyses in the way that the purchase intention was a more influential factor for environmentally oriented eco-friendly clothing than was one's self-reported actual recycling behaviour of textile waste [12-15]. Also, the results showed that purchase intention is more driven by monetary or economic reasons. Furthermore, gender and age were significant factors predicting to oriented eco-friendly clothing behaviours. Various studies suggest that the communities with a collection programme for recyclable textile waste had a $24 \%$ higher participation rate than communities which not oversees the recycling campaign [14-18].

On this background, the statistical hypotheses underlying this research are as follows:

$H_{1}$ : There is a significant relationship between environmentally friendly attitude and purchase intention of textile products coming from the recycling of unused, old or faulty textile products

$\mathrm{H}_{2}$ : There is a significant relationship between financially sustainable and purchase intention of textile products coming from the recycling of unused, old or faulty textile products

$\mathbf{H}_{3}$ : There is a significant relationship between social Influence and purchase intention of textile products coming from the recycling of unused, old or faulty textile products

$\mathbf{H}_{4}$ : There is a significant relationship between behavioural intention and purchase intention of textile products coming from the recycling of unused, old or faulty textile products

\section{RESEARCH METHODOLOGY}

The methodological principles that underpinned the research were the Cartesian principle of analytical division and decomposition and the principle of deductive logical reasoning. Carrying out this research study (at the level of 650 respondents who answered a questionnaire with 35 items with simple and multiple answers), thus contributing to revealing the recycling textile products spirit existing in Turkey, as well as the advantages and disadvantages conferred by the manifestation of the spirit among young people in Turkey, including the risks arising from the implementation of a green business in the context which the Turkish Government aims to increase its textile recycling rate to 35 per cent over the next five years [19-20].

Obviously, it was taken into account that the manifestation of the recycling textile products spirit is directly and indirectly dependent on the conditions of the entity's environment of action (internal and external), as well as on the approach to the risks arising from the following implementation of a business, including different ways of perceiving the green business environment in Turkey.

The quantitative marketing research ran from June to September in 2019 on a sample of over 650 people and used a survey based on questionnaire appropriate to the research objectives. Using the survey, according to the research interests, it was possible to build a sample of individuals with characteristics close to those of the reference population. The criteria for structuring the population included age, gender, and background. In determining the sample size, a random sampling had to take into account both the accuracy level of the estimation (admitted error) and the confidence interval.

At the level of the population surveyed, a sample size (n) of 850 subjects was found and the share of those aged between 40 and 49 the level of the sample it was $16.62 \%$ while the share of the female population at the level of the sample was $72.77 \%$ (table 1 ).

The probability with which the results were guaranteed was $p=95 \%$; therefore, the theoretical value corresponding to the coefficient $t$ in the standardized normal distribution table, specific to a bilateral test, must be 1.96. It has been found that $t$ calc, the population structure criteria (age 40-49 years $=2.87$ and $\operatorname{sex} f=2.06$ ) were higher than their theoretical value (1.96); therefore, the sample in this structure could 
be validated, and the sample was verified by correcting the criteria so that they coincide with the structure of the population surveyed (table 2).

\begin{tabular}{|c|c|c|c|c|}
\hline \multicolumn{5}{|c|}{$\begin{array}{l}\text { DISTRIBUTION OF ADULT POPULATION } \\
\text { AND VALIDATION SAMPLE }\end{array}$} \\
\hline Criteria & $\begin{array}{c}\text { Groups of } \\
\text { subjects } \\
\text { investigated } \\
\text { sample }(P)\end{array}$ & $\%$ & t calc. & $\mathbf{t}$ \\
\hline Age & & & & \multirow{7}{*}{1.96} \\
\hline $18-29$ years & 156 & 24.00 & 0.26 & \\
\hline $30-39$ years & 182 & 28.00 & 0.95 & \\
\hline $40-49$ years & 108 & 16.62 & 2.87 & \\
\hline $50-59$ years & 135 & 20.77 & 0.33 & \\
\hline over 60 years & 69 & 10.62 & 0.14 & \\
\hline Total & 650 & 100 & - & \\
\hline Gender & & & & \multirow{4}{*}{1.96} \\
\hline Male & 177 & 27.23 & 2.90 & \\
\hline Female & 473 & 72.77 & 2.06 & \\
\hline Total & 650 & 100 & - & \\
\hline
\end{tabular}

Table 2

\begin{tabular}{|c|c|c|c|c|}
\hline \multicolumn{5}{|c|}{ SAMPLE REDRESSING STRUCTURE } \\
\hline Criteria & $P_{0}(\%)$ & $P$ - redressed & t calc. & $\mathbf{t}$ \\
\hline Age & & & & \multirow{6}{*}{1.96} \\
\hline $18-29$ years & 23.53 & 23.92 & 0.20 & \\
\hline $30-39$ years & 27.41 & 27.58 & 0.32 & \\
\hline $40-49$ years & 20.55 & 19.14 & 0.08 & \\
\hline $50-59$ years & 20.96 & 21.58 & 0.11 & \\
\hline over 60 years & 7.55 & 7.78 & 0.04 & \\
\hline Sex & & & & \multirow{3}{*}{1.96} \\
\hline Male & 47.81 & 48.42 & 0.09 & \\
\hline Female & 52.19 & 51.58 & 0.09 & \\
\hline
\end{tabular}

\section{RESULTS AND DISCUSSION}

The respondents were asked to assess the importance attributed to the purchase intention related to textile products coming from the recycling of unused, old or faulty textile products based on the perceptions of the environmentally friendly, financially sustainable, social Influence and behavioural intention. Their answers are quantified by an ordinate scale with a five-semantic differentiation, where $(+1)$ represents "insignificant" and (+5) "extremely important".

Testing of the $H_{1}$ hypothesis: There is a significant relationship between environmentally friendly attitude and purchase intention of textile products coming from the recycling of unused, old or faulty textile products

The results of the survey show that over $50 \%$ of the valid responses of young people, adults and the elderly have indicated that environmentally friendly is an important factor in the decision-making process of purchasing textile products coming from the recycling of unused, old or faulty textile products (figure 1).

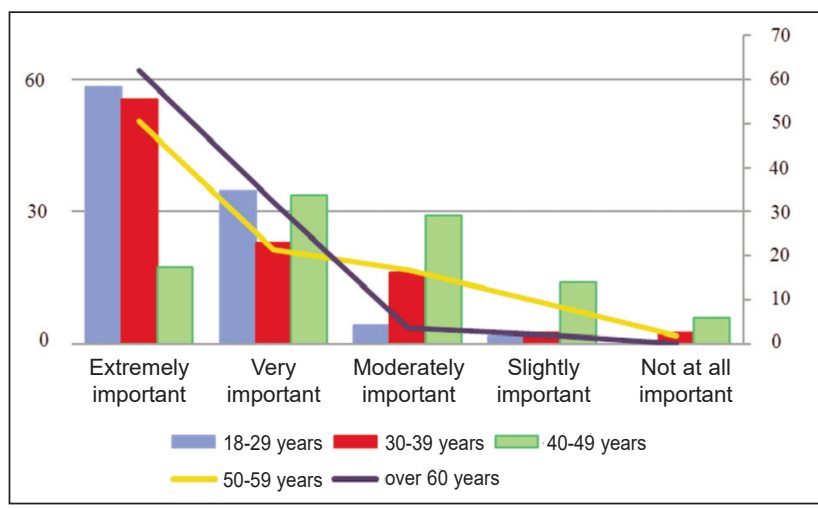

Fig. 1. The environmentally friendly factor on the criterion purchase intention

The first null hypothesis of research states that the respondents' age and environmentally friendly does not significantly affect statistically the importance of the purchasing textile products coming from the recycling of unused, old or faulty textile products.

Verification of the hypothesis was performed using the $x^{2}$ test for two independent variables. Under conditions of a significance level of 0.05 and of 10 specific categories of variables investigated $(n=5, k=5)$, 16 degrees of freedom $\{n=(r-1)(k-1), n=16\}$ result in an $x_{0.95}^{2}$ of 28.70 . From the comparison $x_{\text {calc. }}^{2}>$ $x_{0.95}^{0}(125.88>28.70)$ it results that the null hypothesis cannot be accepted.

Testing of the $\mathrm{H}_{2}$ hypothesis: There is a significant relationship between financially sustainable and purchase intention of textile products coming from the recycling of unused, old or faulty textile products The second null hypothesis indicates that the gender and financially sustainable of the respondents does not significantly and statistically influence the importance of the purchasing textile products coming from the recycling of unused, old or faulty textile products. Again, the $x^{2}$ test for two independent variables was used to verify the statistical hypothesis. At a significance level of 0.05 , where $r=2$ and $k=5$ and specific categories of variables are examined, it results in four degrees of freedom $\{n=(r-1)(k-1), n=4\}$ to give $x_{0.95}^{2}$ of 9.44 . As $x_{\text {calc. }}^{2}>x_{0.95}^{2}(16.33>9.44)$, it appears that the alternative hypothesis is accepted, the gender and financially sustainable of the respondent significantly influences the importance of the purchase intention criterion (figure 2).

Testing of the $\mathrm{H}_{3}$ hypothesis: There is a significant relationship between social Influence and purchase intention of textile products coming from the recycling of unused, old or faulty textile products

In order to verify the null hypothesis indicating that the social Influence factor did not significantly and statistically influence the importance of the purchase intention criterion, the $x^{2}$ test for two independent variables was used (figure 3 ). 


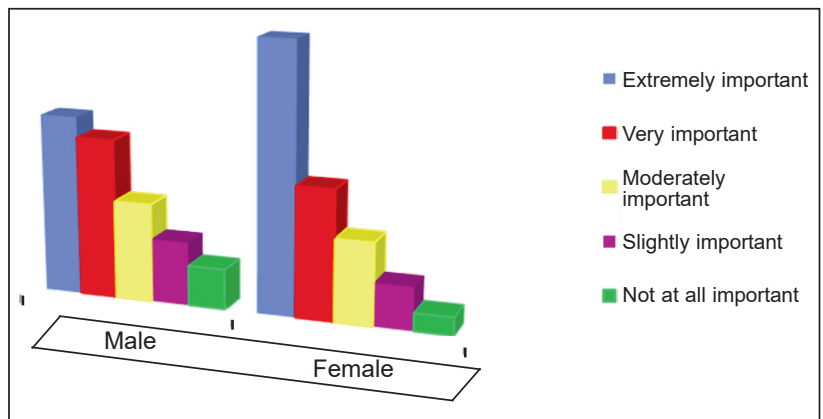

Fig. 2. The financially sustainable factor on the criterion purchase intention

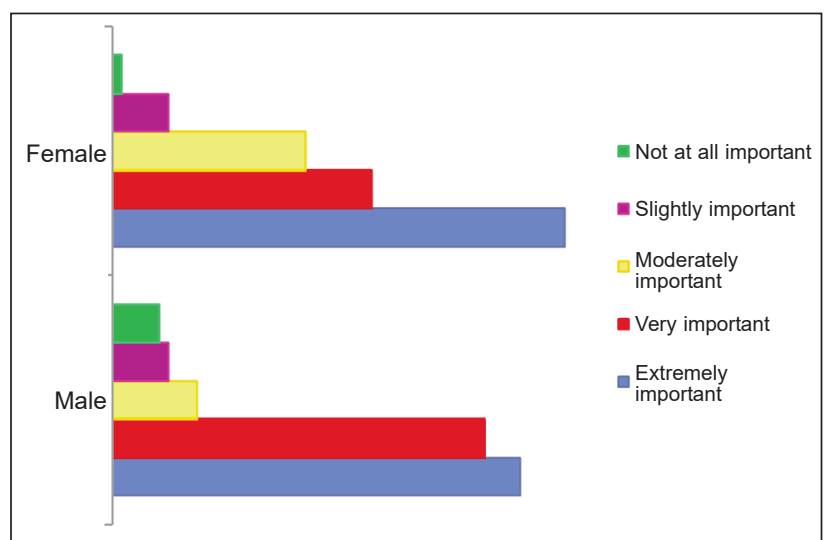

Fig. 3. The social Influence factor on the criterion purchase intention

Testing of the H4 hypothesis: There is a significant relationship between behavioural intention and purchase intention of textile products coming from the recycling of unused, old or faulty textile products

The following null hypothesis refers to the influence of the behavioural intention on the surveyed population in regard to the purchase intention of textile products in the previous year. Because $x_{\text {calc. }}^{2}(9.80)$ is higher than $x_{0.95}^{2}(5.20)$, the null hypothesis was rejected; therefore, the variable behavioural intention is influenced by the respondents 'purchase intention of textile products coming from the recycling of unused, old or faulty textile products. Cramer's coefficient $\Phi_{c}$ was used following the identification of the surveyed population's opinions on behavioural intention and the way they are influenced by the purchase intention of textile products criterion. Figure 4 shows that to meet the minimum condition of this test, the age variable was grouped into three distinct categories: young people (18-29 years), adults (30-59 years), and the elderly (over 60 years).

Other factors like environmentally friendly $[0.248$, $p<0.05]$, financially sustainable $[0.152, p<0.05]$ and social Influence $[0.105, p<0.05]$ too showed significant and positive paths to the behavioural intention of purchasing green textile, in their order of influencing strength.

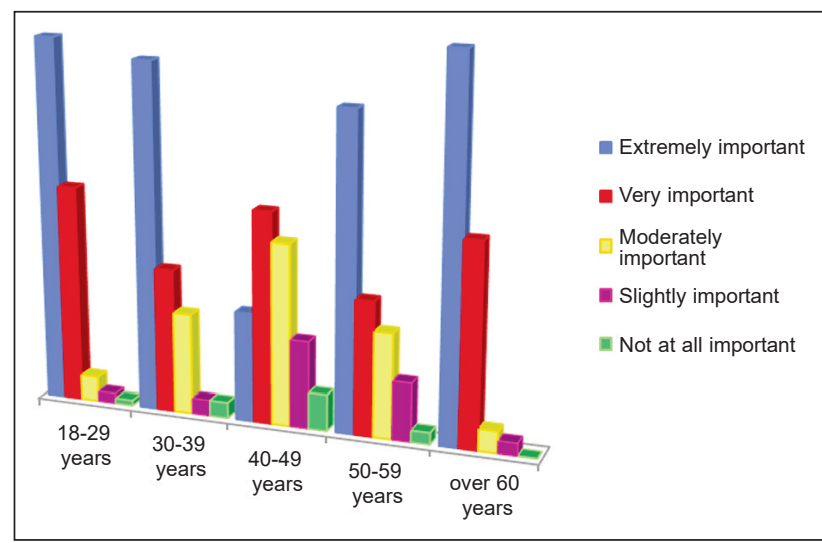

Fig. 4. The behavioural intention factor on the criterion purchase intention

\section{CONCLUSIONS}

Understanding behavioural intention and knowing customers is never a simple job because consumer behaviour regarding purchase intention of textile products coming from the recycling of unused, old or faulty textile products is dynamic, constantly changing and evolving.

The results of this quantitative research show important aspects related to the attitudes, motives, and experiences of the population regarding the purchase intention of textile products coming from the recycling of unused, old or faulty textile products and describe the evolution of the textile market shares of products analysed based on the perceptions of the population from Turkey.

After analysing the data, the present research also illustrates that necessary condition for studying behavioural intention to preserve the company's textile market share. Our work contributes to this important issue by demonstrating that the textile products coming from the recycling of unused, old or faulty textile products does not depend only on the age of the population.

At the same time, the results of our study can be a real support for the Turkish Ministry of Environment and Urbanization, which oversees the textile recycling campaign, in supporting the partnerships between public and private companies to establish a textile waste collection system as part of nationwide campaign.

Moreover, the findings are especially useful because the Turkish manufacturers can take into account them in view improving their activity, in order to eliminate the shortcomings and discrepancies in the client-client relationship. Improving this relationship will attract potential customers, allow customer loyalty and, implicitly, increase credibility.

\section{ACKNOWLEDGEMENTS}

This research has been done under Supporting Civil Society Dialogue between EU and Turkey (CSD-V) Grant Scheme, which is financed by European Union. 


\section{REFERENCES}

[1] Domina, T., Koch, K., Convenience and frequency of recycling implications for including textiles in curbside recycling programs, In: Environment and Behavior, 2002, 34, 216-238

[2] Macarthur, E, Zumwinkel, K., Stuchtey, M.R., Growth within: a circular economy vision for a competitive Europe, Ellen MacArthur Foundation: Cowes, UK, 2015

[3] Hawley, J.M. Textile recycling: A systems perspective, In: Recycling in textiles. Woodhead Publishing Limited, UK, 2008

[4] Atilgan, T., Kanat, S., The effects of the EU customs union with Turkey on the Turkish textile and clothing sector, In: Fibres \& Textiles in Eastern Europe, 2006, 4, 58, 11-15

[5] Kaya, Y., Karakan, G.G., Visileanu, E., The impact of foreign exchange movements on Turkish textile sector, In: Industria Textila, 2019, 70, 3, 291-296, https://doi.org/0.35530/lT.070.03.1591

[6] Altun, Ş., Prediction of Textile Waste Profiles and Recycling Opportunities in Turkey, In: Fibres \&Textiles in Eastern Europe, 2012, 94, 5, 16-20

[7] Pensupa, N., Leu, S.Y., Hu, Y., Du, C., Liu, H., Jing, H., Lin, C.S.K., Recent trends in sustainable textile waste recycling methods: Current situation and future prospects, In: Topics in Current Chemistry, 2017, 375, 5, 76

[8] Weber, S., Lynes, J., Young, S.B., Fashion interest as a driver for consumer textile waste management: reuse, recycle or disposal, In: International Journal of Consumer Studies, 2017, 41, 2, 207-215

[9] Coskun, G., Basaran, F.N., Post-Consumer Textile Waste Minimization: A Review, In: Journal of Strategic Research in Social Science, 2019, 5, 1, 1-18

[10] Ekström, K.M., Salomonson, N., Reuse and Recycling of Clothing and Textiles-A Network Approach, In: Journal of Macromarketing, 2014, 34, 3, 383-399

[11], Joung, H.M., Park $\square$ Poaps, H., Factor s motivating and influencing clothing disposal behaviours, In: International Journal of consumer studies, 2013, 37, 1,105-111

[12] Laitala, K., Consumers' clothing disposal behavior - a synthesis of research results, In: International Journal of Consumer Studies, 2014, 38, 5, 444-57

[13] Gabrielli, V., Baghi, I., Codeluppi, V., Consumption practices of fast fashion products: a consumer-based approach, In: Journal of Fashion Marketing and Management: An International Journal, 2013, 17, 2, 206-224

[14] Pulat, E., Etemoglu, A.B., Can, M., Waste-heat recovery potential in Turkish textile industry: Case study for city of Bursa, In: Renewable and Sustainable Energy Reviews, Elsevier, 2009, 13, 3, 663-672

[15] Piribauer, B, Bartl, A., Textile recycling processes, state of the art and current developments: a mini review, In: Waste Manag Res, 2019, 37, 112-119

[16] Kamble, Z., Behera, B.K., Kimura, T., Haruhiro, I., Development and characterization of thermoset nanocomposites reinforced with cotton fibres recovered from textile waste, In: Journal of Industrial Textiles, 2020, 62, 152808372091353

[17] Büyükaslan, E., Jevšnık, S., Kalaoglu, F., A Sustainable Approach to Collect Post-Consumer Textile Waste in Developing Countries, In: Marmara FenBilimleri Dergisi, 2015, 27, 107-111

[18] Morgan, L.R., Birtwistle, G., An investigation of young fashion consumers' disposal habits, In: International Journal of Consumer Studies, 2009, 33, 190-198

[19] The Turkish Statistical Institute, Available at: http://www.turkstat.gov.tr/PreTablo.do?alt_id=1019 [Accessed on April 2020]

[20] Lane, M., Turkey sets ambitious textile recycling targets, Available at: https://apparelinsider.com/turkey-setsambitious-textile-recycling-targets/ [Accessed on April 2020]

\section{Authors:}

\section{IONICA ONCIOIU ${ }^{1}$, ANA MARIA IFRIM ${ }^{1}$, MARIUS PETRESCU ${ }^{2}$, ANCA GABRIELA PETRESCU $^{2}$,} CĂTĂLIN PETCU ${ }^{3}$, CĂTĂLIN IONUȚ SILVESTRU ${ }^{4}$

${ }^{1}$ Titu Maiorescu University, Faculty of Finance-Banking, Accountancy and Business Administration, Department of Business Administration, 04005, Bucharest, Romania e-mail: amifrim@gmail.com

${ }^{2}$ Valahia University, Faculty of Economic Sciences, 130024, Targoviste, Romania e-mail: petrescu.marius_m@yahoo.com, anki.p_2007@yahoo.com

${ }^{3}$ University Politehnica of Bucharest, 060042, Bucharest, Romania e-mail: cata_petcu@yahoo.com

${ }^{4}$ Bucharest University of Economics Studies, 010374, Bucharest, Romania e-mail: catalin@ase.ro

\section{Corresponding author:}

IONICA ONCIOIU

e-mail: ionicaoncioiu@yahoo.ro 